East of East 


\section{Latinidad}

\section{Transnational Cultures in the United States}

This series publishes books that deepen and expand our understanding of Latina/o populations, especially in the context of their transnational relationships within the Americas. Focusing on borders and boundary crossings, broadly conceived, the series is committed to publishing scholarship in history, film and media, literary and cultural studies, public policy, economics, sociology, and anthropology. Inspired by interdisciplinary approaches, methods, and theories developed out of the study of transborder lives, cultures, and experiences, titles enrich our understanding of transnational dynamics.

Matt Garcia, Series Editor, Professor of Latin American, Latino and Caribbean Studies, and History, Dartmouth College

For a list of titles in the series, see the last page of the book. 


\title{
East of East
}

\section{The Making of Greater El Monte}

\author{
EDITED BY ROMEO GUZMÁN, CARRIBEAN FRAGOZA, \\ ALEX SAYF CUMMINGS, AND RYAN REFT
}

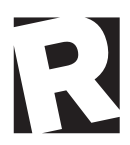

Rutgers University Press

New Brunswick, Camden, and Newark, New Jersey, and London 
Library of Congress Cataloging-in-Publication Data

Names: Guzmán, Romeo, editor. | Fragoza, Carribean, editor. | Cummings, Alex Sayf, editor. | Reft, Ryan, editor.

Title: East of east: the making of greater El Monte/edited by Romeo Guzmán,

Carribean Fragoza, Alex Sayf Cummings, and Ryan Reft.

Description: New Brunswick, New Jersey: Rutgers University Press, [2020] | Series:

Latinidad: transnational cultures in the United States | Includes bibliographical references and index.

Identifiers: LCCN 2019017115 | ISBN 978197880549I (cloth) | ISBN 9781978805484 (pbk.)

Subjects: LCSH: El Monte (Calif.) - History. | El Monte (Calif.) - Social life and customs. |

Popular culture-California-El Monte-History. | El Monte (Calif.) - Biography.

Classification: LCC F869.E4 $\mathrm{E}_{27} 2020$ | DDC 979.4/93-dc23

LC record available at https://lccn.loc.gov/2019017115

A British Cataloging-in-Publication record for this book is available from the British Library.

This collection copyright ( $) 2020$ by Rutgers, The State University of New Jersey

Individual chapters copyright $\left({ }^{\circ} 2020\right.$ in the names of their authors

All rights reserved

No part of this book may be reproduced or utilized in any form or by any means, electronic or mechanical, or by any information storage and retrieval system, without written permission from the publisher. Please contact Rutgers University Press, 106 Somerset Street, New Brunswick, NJ 0890 . The only exception to this prohibition is "fair use" as defined by U.S. copyright law.

๑) The paper used in this publication meets the requirements of the American National Standard for Information Sciences-Permanence of Paper for Printed Library Materials, ANSI Z39.48-1992.

www.rutgersuniversitypress.org

Manufactured in the United States of America 
For Aura, Camila, and the Guzmán and Fragoza clans Romeo Guzmán

To those who imagine radical futures for Greater El Monte Carribean Fragoza

For Betsy and Barbara

Alex Sayf Cummings

For Soo

Ryan Reft 
